\title{
Profiles and Characteristics of Balinese Cattle Breeders in The Covid-19 Era in The Village of Ayunan Badung, Bali
}

\author{
Ni Made Ayu Gemuh Rasa Astiti ${ }^{1)}$, Ni Ketut Madewi ${ }^{1)}$ and Ni Ketut Sri Rukmini ${ }^{1)}$ \\ ${ }^{1}$ Animal Husbandry Department, Agriculture Faculty, Warmadewa University \\ *ayugemuh@gmail.com
}

\begin{abstract}
This study aims to determine the characteristics and profiles of Balinese cattle breeders in Ayunan Village during the Covid-19 pandemic. The method used is a survey method using primary data and secondary data. Sampling was carried out by using a purposive sampling questionnaire to 40 Balinese cattle breeders in Ayunan Village and who have experienced raising cattle for more than three years. The results showed that $77.5 \%$ of farmer respondents were in the productive age range, and $22.5 \%$ were in the age range over 64 years. Young and fertile breeders generally have a high level of education, so they tend to adopt innovation and technology more quickly. Experience increased respondents for 21 years to 30 years (35\%). Long enough farming experience shows that the respondent breeders have adequate knowledge and skills in raising cattle. The education of the respondents $2.5 \%$ has no formal education, $25 \%$ has an elementary education, $12.5 \%$ has a junior high school education and 50\% has a high school education, and 10\% has tertiary education. Farmers' education level tends to influence thinking power and acceptance of innovation and technology. The average number of respondents' livestock ownership is 2.6 heads due to several factors, including limited forage or $20 \%$ of feed, because the determinant of business capital is $42.5 \%$ and cultivated as a side business of $37.5 \%$. The majority of respondents who breeders have the main job as farmers / agricultural laborers $60 \%$, only $5 \%$ of respondents who breeders have the main job as breeders.
\end{abstract}

Keywords: Covid-19, Characteristics, Bali Cows

\section{Introduction}

Covid-19 has changed the order of human life, which is unusual into a habit that must follow for the sake of energy and vitality. Bali cattle is one of the national germplasm that needs to preserve. Bali cattle have the advantages of high fertility, more resilience to unfavorable environmental conditions, quick adaptation when faced with a new environment, fast breeding, and low carcass fat content [1]. The percentage of carcass ranged from 51.5-59.8 percent, with bone percentage less than 15 percent carcass weight and low-fat content [2]. Efforts to increase livestock productivity should be carried out from the beginning so that development and growth in the early days will determine the achievement of development and growth in the future [3].

The village of swing, Abiansemal sub-district, Badung Regency, is surrounded by fertile rice fields and plantations. Ayunan Village's population is \pm 2600 people in 2020 and has 500 hectares, most of which is productive agriculture [4]. Geographically, Ayunan Village in Badung Regency has some untapped potential. [5] Some of the possibilities include large rice fields, the Bali Swadaya cattle group, and the Simantri cattle group. Most breeders raise Balinese cattle to fill their spare time between farming and as savings for expenses that require a large amount of money, such as traditional ceremonies, sending their children to school, and repairing houses. Farmers in managing their business still use the conventional system.

Most of the Balinese cattle business is a small-scale community farming business with Balinese cattle ownership characteristics, which is still low, between (1-5) heads [7]. The number of livestock ownership is still low because the maintenance system is still traditional. In managing the 
people's livestock business, human resources' limited ability is often an obstacle and impacts productivity. For business development and improvement, breeders must change their thinking and develop their characteristics by having several practical knowledge related to the livestock business. As the key to the success of their business, farmers must be able to absorb existing information. Information is an essential factor in enriching farmer knowledge [8].

A person's characteristics affect different ways and abilities in the form of perception, what information is wanted, how to interpret it [9]. Farmers in adopting innovation are very dependent on social and economic factors of farmers. Social factors include age, level of education, and farming experience. Financial elements include income level, number of family dependents, a land area owned, and whether or not livestock businesses are owned by breeders [10]. This socioeconomic factor plays a vital role in managing the livestock business in Bali's cattle breeding business. The number of breeders in the Covid Era is increasing. Still, the problems experienced by breeders, in general, are not continuous availability of feed, especially during the dry season, and the lack of breeders' innovation in making additional feed [11]. The farmer's character is a crucial factor, such as demographic, behavioral, psychographic, and geographic elements.

Demography is one of the variables that often used to see a person's communication skills and their ability to choose media.

Demographics are often variables that often determine a person's communication skills and their ability to select media. Demographic characteristics relate to sources of information. Demographic factors are age, income, education, experience, and cosmopolitanism [12]. Based on the background, a study was conducted on "the characteristics of Balinese cattle breeders in the Ayunan village." Demographics are often variables that often determine a person's communication skills and their ability to choose media. Demographic characteristics relate to sources of information. Demographic factors are age, income, education, experience, and cosmopolitanism [12]. Based on the background, a study was conducted on "the characteristics of Balinese cattle breeders in the Ayunan village." Demographics are one of the variables that do often used to determine a person's communication skills and also their ability to choose media. Demographic characteristics relate to sources of information. Demographic factors are age, income, education, experience, and cosmopolitanism [12].

Formulation of the Problem Based on this background, the research problem's formulation is as follows: What are Balinese cattle breeders' characteristics and profiles in Ayunan Village during the Covid-19 pandemic. Research purposes of determining Balinese cattle breeders' characteristics and profiles in Ayunan village during the Covid-19 pandemic.

\section{Material and Methods}

The research was held for two months from January to February 2021 in Ayunan Village, Badung Regency, Bali, by taking a sample of 40 Balinese cattle breeders. The research method used is a survey method using primary data and secondary data. Sampling was done by purposive sampling. Secondary data related to the research was obtained from the Department of Animal Husbandry and Animal Health, Bali Province. Qualitative Data includes:

1. Characteristics of respondents, among others: age of farmer, number of family members. This type of research is qualitative descriptive research that aims to determine Balinese cattle breeders' characteristics in Ayunan Village, Abiansemal, Badung. Objects/subjects with specific qualities and characteristics do determine by the researcher to be studied and then conclude. The population in this study were Balinese cattle breeders in Ayunan Village, Abiansemal, Badung. 
2. Samples do obtain from distributing questionnaires to 40 Balinese cattle breeders in the Ayunan village. The respondents chosen were Balinese cattle breeders who had been breeding for at least three years.

3. Data Collection Techniques, data collection techniques, namely: 1. Observation, direct observation of the condition of the Bali cattle breeder research location and its various activities. 2 . Direct interviews with breeders engaged in the Bali cattle business. 3. Questionnaire using a list of questions that have gives to Balinese cattle breeders.

4. Data sources In this study, the data used is quantitative because it does express by numbers indicating the value of the magnitude of the variables it represents. Types of data are primary data and secondary data. Primary Data is data obtained directly from the object to review. Secondary Data is a data source that now provides data to data collectors. Primary data obtained from interviews conducted. Secondary Data Secondary data from records in the literature related to this study and data from government offices and related agencies. Data sources do not directly provide data to data collectors through other people or documents.

5. The data analysis method used in this study is a qualitative descriptive analysis of the percentage. This method is used to examine the study variables, namely the characteristics of Balinese breeders and cattle. The illustrative rate process by dividing the frequency by the number of respondents multiplied by $100 \%$. are as follows: P = F x 100\% N Information: P: Percentage of answers F: Frequency of values obtained from all items N: Number of respondents 100\%: Fixed numbers In this study using the percentage formula is the answer to the questionnaire that has distributed, Then each solution is analyzed with a percentage formula, namely the number of responses divided by the total number of respondents then multiplied by a fixed number, namely $100 \%$.

\section{Results and Discussion}

\subsection{General Description of The Research Location}

Badung Regency is one of 9 regencies/municipalities in Bali Province and is located in the middle of Bali Island, stretching from north to south end. Geographically, Badung Regency is located between 8014'20 "-8050'48" South Latitude and 115005'00 "-115026'16" East Longitude [13].

Administratively, Badung Regency consists of six sub-districts, namely Petang, Abiansemal, Mengwi, Kuta, North Kuta, and South Kuta districts 62 villages sub-districts. Badung Regency has $418.52 \mathrm{Km} 2$, with the land's designation as rice fields covering an area of 29,970 hectares, dry land covering an area of 8,191 . Ha, plantation area of 6,420 ha, community forest of 2,122 ha, idle land of 231 ha, 2,811 ha of land designated for ponds/ponds, and 11,882 ha of non-agricultural land (roads, settlements, offices, etc.).

The Badung Regency area's condition varies greatly, so it divides into three parts: the northern part of Badung, the central region, and the southern part. The northern part of Badung Regency, namely Petang and Abiansemal Districts, is a mountainous area with cool air. The Abiansemal subdistrict has an altitude of 75-350 m above sea level. Meanwhile, Petang District, which is at the northern tip, is at an altitude of $275-2075 \mathrm{~m}$ above sea level. The dominance of community activities in the north of Badung is plantation activities and agro-tourism. The northern part of Badung is bordered by Buleleng Regency The central part of Badung Regency, namely Mengwi District, has a height between 0-350 $\mathrm{m}$ above sea level. Mengwi sub-district is a rice field area dominated by agricultural activities and cultural tourism. The central part of Badung is bordered by Gianyar Regency and Denpasar City in the east, while in the west, it does connect by Tabanan Regency. 
The southern part of Badung is a lowland with an altitude ranging from 6.6-65 m above sea level, with white sandy beaches. Community activities of south Badung do dominate by tourism, trade, and education activities. The southern part of Badung is directly adjacent to the Indonesian Ocean.

The research location which is located in Ayunan Village, Abiansemal District, Badung Regency is an agro-tourism and plantation area and most of the population raises Bali cattle. Nearly every household raises cows in the back of their house as an investment and part-time business between their main jobs.

\subsection{The Characteristics of Balinese Cattle Breeders in Ayunan village Respondent Age}

Working productive age based on the Manpower Law No. 13 of 2003 Chapter I article 1 paragraph 2 is every person who can produce goods and services to fulfill their own needs or for the community in the age range of $15-64$ years [14]. Based on these regulations, it can seem that several $77.5 \%$ of these respondent breeders are in the productive age range, and $22.5 \%$ are in the age range above 64 years (Table 1).

Table 1

Distribution of Respondents by Age

\begin{tabular}{llll}
\hline \multirow{2}{*}{ Serial number } & $\begin{array}{l}\text { Age } \\
(\text { Year })\end{array}$ & Respondents & \\
\cline { 3 - 4 } & & Amount (Person) & Percent $(\%)$ \\
\hline 1 & $\leq 20$ & 0 & 0 \\
2 & $21-35$ & 1 & 2.5 \\
3 & $36-50$ & 5 & 12.5 \\
4 & $51-64$ & 25 & 62.5 \\
5 & $\geq 65$ & 9 & 22.5 \\
\hline Total & 40 & 100 \\
\hline \multicolumn{2}{l}{ Data Sources: Results of Data Processing } & &
\end{tabular}

Older breeders are usually passionate about tradition, and it is challenging to provide insights that can change the way they think, work, and live. Older breeders are generally apathetic towards innovation, while young and productive breeders typically have high morale, high curiosity, and increased interest in adopting innovations [15]. Young breeders generally have a high education level, so they tend to adopt innovations and technologies more quickly [16]. The high percentage of respondent breeders in the productive age will provide an excellent opportunity to increase their livestock business productivity further.
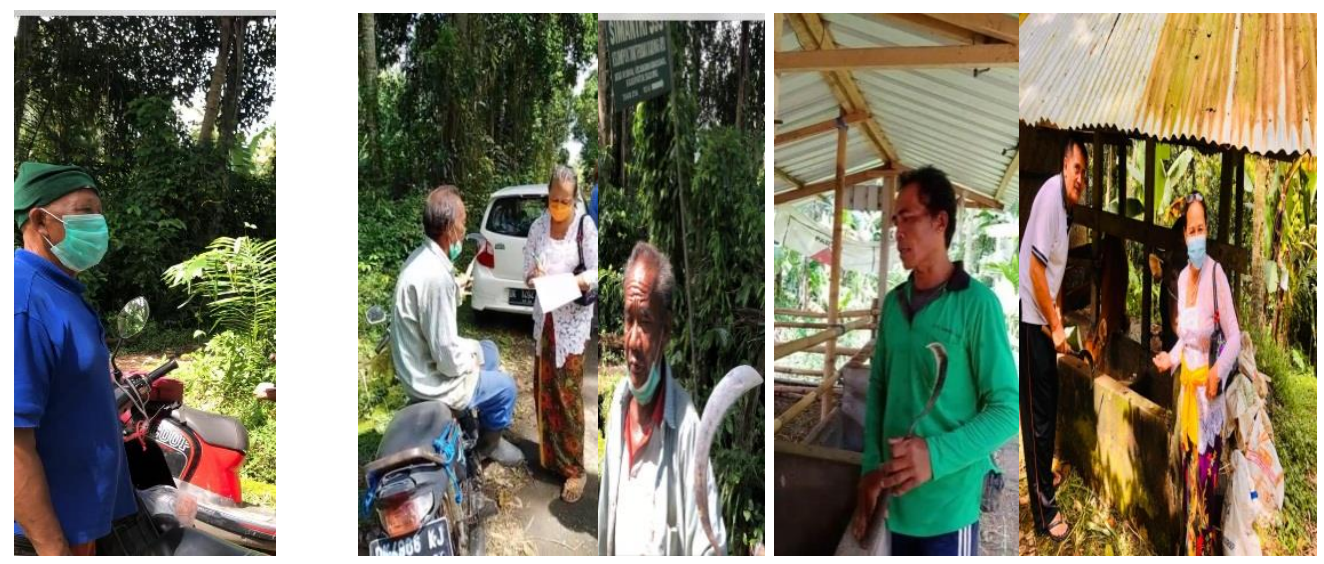

Figure 1

Profile of Cattle Farmers in Ayunan Village 


\section{Livestock Experience}

The experience of raising cows from respondents show in Table 2, where most of the respondents (35\%) have had 21 to 30 years of farming experience; this indicates that raising cattle has been hereditary as a free time filler and utilizing between yards.

Table 2

Experience Raising Cows

\begin{tabular}{llll}
\hline \multirow{2}{*}{ No. } & Time & Livestock Experience & \\
\cline { 3 - 4 } & (Year) & Amount (Person) & Percent $(\%)$ \\
\hline 1 & $<3$ & 2 & 0 \\
2 & $3-10$ & 8 & 5.0 \\
3 & $11-20$ & 14 & 20.0 \\
4 & $21-30$ & 13 & 35.0 \\
5 & $31-40$ & 3 & 32.5 \\
6 & $>40$ & 40 & 7.5 \\
\hline Total & & & 100 \\
\hline
\end{tabular}

Data Sources: Results of Data Processing

The experience of raising cattle is the amount of time the farmer spends in the cattle breeding business [17]. Knowledge can be a joint for the development of science. In running a business, breeders will find many new things. If these new things are observed and learned as part of knowledge, the length of time spent in raising livestock will provide the farmer with knowledge and skills. Long farming experience indicates that the respondent breeders have adequate knowledge and skills in cattle raising [18]. This statement is in line with [19] The more experienced a person is, and the more his / her skills will be. More extended experience in a business can affect attitudes, thought patterns, and breeders' behavior in running their business. That experience is a foundation for knowing when a person works, and he will encounter new things. If he understands new things as knowledge to belong to him, he has gained unique work experience. To achieve a talent or skill requires repeated or continuous practice of what is learned by regularly doing it. It can be refined and put on standby [20].

\section{Length of Education}

The length of education from the study results was $2.5 \%$ had no formal education, $25 \%$ had elementary school education, $12.5 \%$ had junior high school education, 50\% had high school education, and 10\% received a college education in Table 3 and Figure 2. The data regarding the distribution of farmer education levels has excellent potential to develop human resources for breeders because it will be easier for them to accept innovations helpful in increasing business efficiency [21]. Farmers' education level tends to influence their thinking power and their level of acceptance of designs and technologies [22]. Formal and non-formal education is a smoothing factor in livestock development because education, knowledge, and human thinking will increase their business [23].

Table 3

Distribution of Respondent Farmers based on Length of Formal Education

\begin{tabular}{llll}
\hline \multirow{2}{*}{ No. } & $\begin{array}{l}\text { Lama Pdd } \\
\text { (Year) }\end{array}$ & Respondents & \\
\cline { 3 - 4 } & 0 & Amount (person) & Percent $(\%)$ \\
\hline 1 & $1-6$ & 10 & 2.5 \\
2 & $7-9$ & 5 & 25.0 \\
3 & $10-12$ & 20 & 12.5 \\
4 & $13-18$ & 4 & 50.0 \\
5 & & 40 & 10.0 \\
\hline TOTAL & & & 100 \\
\hline
\end{tabular}




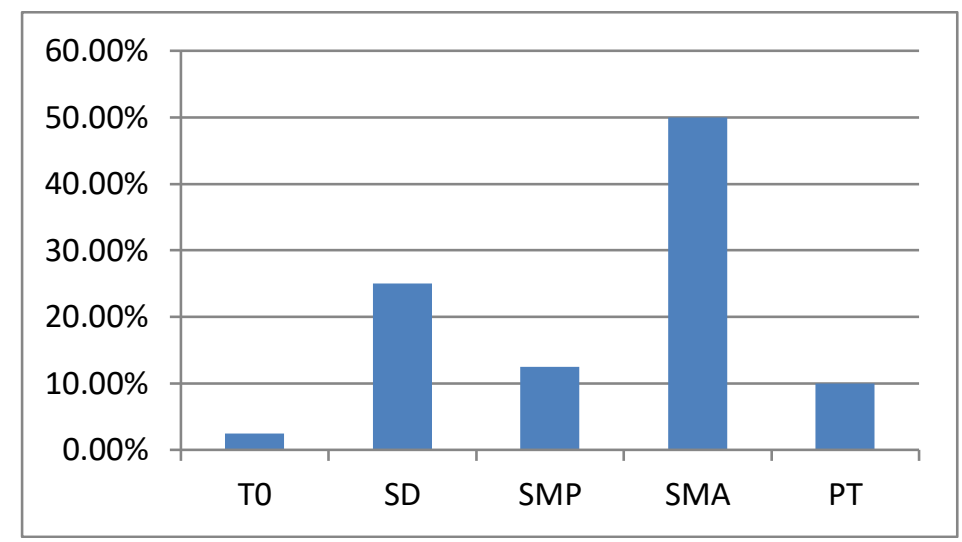

Figure 2.

Distribution of Respondent Farmers based on Length of Formal Education

\section{Total Livestock Ownership}

The respondents' number of livestock ownership averaged 2.6 heads, consisting of 0.50 bulls, 1.13 cows, 0.45 male calves, and 0.52 female calves. (Table 4 ).

Table 4

Total Livestock Ownership

\begin{tabular}{|c|c|c|c|}
\hline \multirow{2}{*}{$\begin{array}{l}\text { Category } \\
\text { Livestock }\end{array}$} & \multirow{2}{*}{$\begin{array}{l}\text { Type } \\
\text { Sex }\end{array}$} & \multicolumn{2}{|c|}{ Respondents } \\
\hline & & $\begin{array}{l}\text { amount } \\
\text { (Tail) }\end{array}$ & $\begin{array}{l}\text { Average } \\
\text { (Tail) }\end{array}$ \\
\hline Adult & Male & 20 & 0.50 \\
\hline Adult & Female & 45 & 1.13 \\
\hline Calves & Male & 18 & 0.45 \\
\hline Calves & Female & 21 & 0.52 \\
\hline Total Average & & 104 & 2.6 \\
\hline
\end{tabular}

Based on the results of the research that has been done, it was found that the current number of livestock ownership is not the maximum number of breeders' ability to maintain, that the maximum ability of breeders in maintaining cows is 5.03 cows on average with a range of three (3.41\%), four heads $(36.36 \%)$, Five heads $(32.95 \%)$, six heads $(18.18 \%)$, seven heads $(5.68 \%)$ with the same maintenance pattern as has been done so far. Besides that, not all breeders have calves, only $0.5 \%$ have male calves, and $0.96 \%$ have female calves [24].

\section{Causes of Low Livestock Maintenance}

The low number of livestock raising does cause by several factors, including breeders who still have problems in increasing the scale of their business, which does cause by several factors, namely the limiting factor of forage or $20 \%$ fodder, then due to the limited business capital factor of $42.5 \%$ and being cultivated as a side business $37.5 \%$ (Table 5). As many breeders raise cows, the higher the farmer's attention to their cows and the increasing number of cows grown, breeders and their families' experience in raising cows will increase [25].

Table 5

Factors Causing Low Amount of Livestock Maintenance

\begin{tabular}{lll}
\hline Factor & Respondents & \\
\cline { 2 - 3 } Cause & $\begin{array}{l}\text { amount } \\
\text { (person) }\end{array}$ & $\begin{array}{l}\text { Percent } \\
(\%)\end{array}$ \\
\hline Limitations of Forage & 8 & 20.0 \\
Limited Business Capital & 17 & 42.5 \\
As a Side Business & 15 & 37.5 \\
\hline TOTAL & 40 & 100 \\
\hline
\end{tabular}




\section{Main Occupation of Respondents}

The majority of respondent breeders have their primary job as farmers/farm laborers $60 \%$, only $5 \%$ of respondent breeders have the main job as breeders. In comparison, $35 \%$ of respondents have jobs as retirees, construction workers, laborers, agricultural extension workers, and traders (Table $6)$.

Table 6

Main Occupation of Respondents

\begin{tabular}{lll}
\hline The main job & Kab.Buleleng & \\
\cline { 2 - 3 } Respondents & $\begin{array}{l}\text { amount } \\
\text { (person) }\end{array}$ & $\begin{array}{l}\text { Percent } \\
(\%)\end{array}$ \\
\hline Breeder & 2 & 5 \\
Farmer & 24 & 60 \\
$\begin{array}{l}\text { Others (Driver, Extension, } \\
\text { Retired, Builder, Laborer, } \\
\text { trade, fisherman) }\end{array}$ & 14 & 35 \\
\hline TOTAL & & \\
\hline Dat Sources: Resuts of & 40 & 100 \\
\hline
\end{tabular}

Data Sources: Results of Data Processing

In general, cattle in Bali are part-time. The survey results showed $5 \%$ of respondents have the main job as breeders. His career is as a farmer $(74.19 \%)$ while raising cows/livestock only parttime between farming [26].

\section{Conclusion}

The profile and characteristics of Balinese cattle breeders in Ayunan Village, seen from the age of the breeders, have the highest percentage (62.5\%) at the age of 51-64 and are classified as productive. $35 \%$ experience in farming (21-30) years, most of the education level is high school graduates (50\%), average livestock ownership is 2.66 tails, the low number of livestock ownership is due to business capital $42.5 \%$ and the main occupation of respondents is $60 \%$ the farmer.

\section{Acknowledgments}

Thank you to all those who have helped to contribute and thought in completing this research.

\section{References}

[1] Diwyanto, K. and L. Praharani. 2010. Reproduction management and strategic breeding to improve productivity and quality of cattle. Abstracts International Seminar Conservation and Improvement of World Indigenous Cattle. 3rdQ4th September. Udayana University, Denpasar BaliQIndonesia.

[2] Handiwirawan, E. and Subandriyo. 2004. The potential and diversity of genetic resources of Bali cattle. Wartazoa 14 (3): 107Q115.

[3] Muladno. 2012. The Application of Seedling Technology to Increase the Production of Meat and the Quality of the National Cows. Proceedings of the National Seminar on the Improvement of the Production and Quality of the National Bali Beef. Bali, 14 September 2012.

[4] Monograph and Population Data of Abiansemal Badung District 2018. Central Statistics of Bali Province. Denpasar.

[5] Ismirandy. A. 2018. Growth Rate and Body Size of Bali Cattle Off Weaning Given Concentrate Feed-in Different Weight Categories. Essay. Department of Animal Science, Faculty of Science and Technology, Alauddin State Islamic University, Makassar.

[6] Sampurna, IP, IK Saka, IG Oka, And P. Sentana. 2013. Biplot Simulation Of Exponential Function To Determine Body Dimension's Growth Rate Of Bali Calf. Canadian Journal On Computing In Mathematics, Natural Science, Engineering And Medicine, 4 (1): 8792.

[7] Putri, BRT, Bidura, IGNG, Partama, IBG, Hellyward, J., \& Inggriati, NWT (2017). The strategy of Business Development Based on Potential Area of Livestock in Gianyar Regency. In International Seminar on Tropical Animal Production (ISTAP) (pp. 515-521). 
[8] Diwyanto, K. (2008). Utilization of local resources and technological innovation in supporting the development of beef cattle in Indonesia. Agricultural Innovation Development, 1 (3), 173-188.

[9] Soekartawi, S. (2007). E-Agribusiness: Theory and Application. In the National Seminar on Information Technology Applications (SNATI).

[10] Djaenudin, D. (2008). Development of research on land resources and their contribution to addressing the need for agricultural land in Indonesia. Journal of Agricultural Research, 27 (4), 137-145.

[11] Astiti, NMAGR, Rukmini, NKS, Rejeki, IGADS, \& Balia, RL (2019). The farmer socio-economic profile and marketing channel of Bali-calf at Bali province. Series "Management, Economic Engineering In Agriculture And Rural Development, " 19 (1), 47-51.

[12] Kusanti, O., \& Andayani, A. (2015). The Effect of Good Corporate Governance and Financial Ratios on Financial Distress. Journal of Accounting Science and Research (JIRA), 4 (10).

[13] Central Bureau of Statistics of Badung Regency, Bali. 2020. Badung Regency in Numbers.

[14] Priyadi, U. (2013). WORKER LEGAL ASSISTANCE (PRODUCTIVE AGE) BASED ON LABOR LAW. Asian Journal of Innovation and Entrepreneurship, 2 (02), 99-103.

[15] Abdullah, A. (2008, November). The role of extension workers and livestock farmer groups to increase the adoption of technology in beef cattle farming. In Proceedings of the National Seminar on Beef Cows, Palu (ID). Faculty of Animal Husbandry Hasanuddin University Makassar, South Sulawesi (ID).

[16] Waris, W., Badriyah, N., \& Aspriati, DW (2019). The influence of education level, age, and length of raising on knowledge of beef cattle reproduction management in Kedungpring Village, Balongpanggang District, Gresik Regency. International Journal of Animal Science, 2 (02), 62-66.

[17] Dwijatmiko, S. (2020). Motivation Relationship Towards Zootechnical Behavior Of Dairy Cow Members Of The Livestock Tank Group In Getasan Sub-District, Semarang District (The Relations Between Motivation And The Zootechnical Behavioral of Dairy District Group, Semarang District). Journal of Agricultural Sciences, 6 (1), 14.

[18] Halim, S. (2017). The Effect of Farmer Characteristics on Motivation to Breed Beef Cattle in Bangkala Village, Maiwa District. Essay. Hasanuddin University Faculty of Animal Husbandry.

[19] Supriyanto, S., Fidin, NI, Nurdayati, N., \& Zuliyana, I. (2020). The Influence of Farmer Characteristics on Breeding Motivation in Kalirejo Village, Salaman District, Magelang Regency. Proceedings of Animal Science.

[20] Astiti, Ni Made Ayu Gemuh Rasa (2019, November). Toward Achieving Self-Sufficiency Livestock. In IOP Conference Series: Earth and Environmental Science (Vol. 347, No.1, p. 012041). IOP Publishing.

[21] Hartono, B. (2012). The role of the carrying capacity of the region in the development of Madura cattle farming. Journal of Development Economics: The Study of Economic and Development Problems, 13 (2), 316-326.

[22] Waris, W., Badriyah, N., \& Aspriati, DW (2019). The influence of education level, age, and length of raising on knowledge of beef cattle reproduction management in Kedungpring Village, Balongpanggang District, Gresik Regency. International Journal of Animal Science, 2 (02), 62-66.

[23] Mulyawati, IM, Mardiningsih, D., \& Satmoko, S. (2016). The influence of age, education, experience, and several goat breeders on the behavior of goat breeding business in Wonosari Village, Patebon Subdistrict. Agromedia: Periodic Scientific Agricultural Sciences, 34 (1).

[24] Krisna, R. (2014). The Relationship of Ownership Level and Business Costs with Beef Cattle Farmer's Income in Sukabumi Regency, West Java Province (Correlation Study). Journal of Management Applications, 12 (2), 295-305.

[25] Rusdin, R. (2012). Several Factors That Influence The Response of the Beef Cattle Farming Community in Parigi Moutong Regency. Agroland: Journal of Agricultural Sciences, 16 (4).

[26] Astiti, NMAGR, Suparta, IN, Lanang Oka, IG, \& Antara, I. (2016). Marketing systems of calf Bali. International Research Journal of Engineering, IT \& Scientific Research (IRJEIS), 2 (11), 73-80. 